A C T A C H E M I A S C A N D I N A V I A 22 (1968) 2003-2011

\title{
Protolysis of Nitrous Acid in Aqueous Sodium Nitrate and Sodium Nitrite Solutions at Different Temperatures
}

\author{
JOUNI TUMMAVUORI and PAAVO LUMME \\ Department of Chemistry, University of Jyväskylä, Jyväskylä, Finland

\begin{abstract}
Values of the protolysis constant of nitrous acid in aqueous sodium nitrate and sodium nitrite solutions at different ionic strengths have been determined potentiometrically at $15^{\circ}, 20^{\circ}, 25^{\circ}$, and $35^{\circ} \mathrm{C}$. The values of the thermodynamic protolysis constant at these temperatures were obtained by extrapolating the data to zero ionic strength using equations of the Debye-Hückel type. The thermodynamic quantities, free energies, enthalpies, entropies, and heat capacities, of the protolytic equilibria were evaluated. The results are discussed.
\end{abstract}

In some recent papers ${ }^{1-3}$ we considered the published values of the ionizaItion constant of nitrous acid and the thermodynamics of its protolysis in aqueous sodium perchlorate solutions at $15^{\circ}, 20^{\circ}, 25^{\circ}$, and $35^{\circ} \mathrm{C}$. We have since extended the measurements to determine the effect of neutral sodium nitrate and high concentrations of sodium nitrite on the protolysis of nitrous acid. The results are presented here.

\section{EXPERIMENTAL}

The methods, apparatus and reagents used in this study were the same as in the earlier studies. ${ }^{2,3}$ The cells were of the following type (Series $A=$ aqueous sodium nitrate solutions of constant sodium nitrite concentration; Series $\mathrm{B}=$ aqueous sodium nitrite solutions of constant nitrate concentration, moles per litre at $20^{\circ} \mathrm{C}$ ):

\begin{tabular}{l|l} 
Glass el. & $\begin{array}{l}\text { Series } \mathrm{A} 100 \mathrm{ml} \\
0.01 \mathrm{M} \mathrm{NaNO}, 0.01 \mathrm{M} \mathrm{NaCl} \\
(I-0.02) \mathrm{M} \mathrm{NaNO}_{3} \\
\text { Series } \mathrm{B} 100 \mathrm{ml} \\
0.03 \mathrm{M} \mathrm{NaNO}, 0.01 \mathrm{M} \mathrm{NaCl} \\
(I-0.04) \mathrm{M} \mathrm{NaNO}_{2}\end{array}$
\end{tabular}|| $\begin{gathered}0.01 \mathrm{M} \mathrm{NaCl} \\
(I-0.01) \mathrm{M} \mathrm{NaNO}_{3}\end{gathered} \mid \mathrm{Hg}_{2} \mathrm{Cl}_{2}, \mathrm{Hg}$

The compositions of the different solutions (molarities at $20^{\circ} \mathrm{C}$ ) are given in Table 1 .

Acta Chem. Scand. 22 (1968) No. 6 
Table 1. Composition of the solutions.

\begin{tabular}{|c|c|c|c|c|c|}
\hline \multirow[b]{2}{*}{$\begin{array}{c}\text { Ionic } \\
\text { strength } \\
I\end{array}$} & \multicolumn{3}{|c|}{ Titrant } & \multicolumn{2}{|c|}{ Studied solutions } \\
\hline & $\begin{array}{l}\text { Ref.elect. } \\
0.01 \mathrm{M} \mathrm{NaCl} \\
\mathrm{M} \mathrm{NaNO}_{3}\end{array}$ & $\begin{array}{c}0.10 \mathrm{M} \\
\mathrm{CH}_{3} \mathrm{COOH} \\
0.01 \mathrm{M} \mathrm{NaCl} \\
\mathrm{M} \mathrm{NaNO}\end{array}$ & $\begin{array}{c}\text { Ref.buff.sol. } \\
0.005 \mathrm{M} \mathrm{HClO} \\
0.01 \mathrm{M} \mathrm{NaCl} \\
\mathrm{M} \mathrm{NaNO}\end{array}$ & $\begin{array}{c}\text { Series A } \\
0.01 \mathrm{M} \mathrm{NaCl} \\
0.01 \mathrm{M} \mathrm{NaNO}_{2} \\
\mathrm{M} \mathrm{NaNO}_{3}\end{array}$ & $\begin{array}{c}\text { Series B } \\
0.01 \mathrm{M} \mathrm{NaCl} \\
0.03 \mathrm{M} \mathrm{NaNO}_{3} \\
\mathrm{M} \mathrm{NaNO}_{2}\end{array}$ \\
\hline 0.09 & 0.08 & 0.08 & 0.075 & 0.07 & 0.05 \\
\hline 0.25 & 0.24 & 0.24 & 0.235 & 0.23 & 0.21 \\
\hline 0.50 & 0.49 & 0.49 & 0.485 & 0.48 & 0.46 \\
\hline 1.00 & 0.99 & 0.99 & 0.985 & 0.98 & 0.96 \\
\hline 2.00 & 1.99 & 1.99 & 1.985 & 1.98 & 1.96 \\
\hline 4.00 & 3.99 & 3.99 & 3.985 & 3.98 & - \\
\hline
\end{tabular}

RESULTS AND DISCUSSION

A. The protolysis of nitrous acid

As previously, the following two protolytic equilibria were assumed to prevail in the titrated solutions: ${ }^{2}$

$$
\begin{aligned}
& \mathrm{HNO}_{2}+\mathrm{H}_{2} \mathrm{O} \rightleftharpoons \mathrm{NO}_{2}^{-}+\mathrm{H}_{3} \mathrm{O}^{+} \\
& \mathrm{CH}_{3} \mathrm{COOH}+\mathrm{H}_{2} \mathrm{O} \rightleftharpoons \mathrm{CH}_{3} \mathrm{COO}^{-}+\mathrm{H}_{3} \mathrm{O}^{+}
\end{aligned}
$$

On applying the mass-action law to these equilibria and noting the total concentrations and the electroneutrality principle, it follows that the protolysis constant of nitrous acid

where

$$
K=\left[\mathrm{H}_{3} \mathrm{O}^{+}\right]\left(C-A+\left[\mathrm{H}_{3} \mathrm{O}^{+}\right]\right) /\left(A-\left[\mathrm{H}_{3} \mathrm{O}^{+}\right]\right)
$$

$$
A=K_{\mathrm{Ac}} C_{\mathrm{Ac}} /\left(K_{\mathrm{Ac}}+\left[\mathrm{H}_{3} \mathrm{O}^{+}\right]\right)
$$

and $K_{\mathrm{Ac}}$ is the concentration ionization constant of acetic acid, which was calculated from the equation

$$
\mathrm{p} K=\mathrm{p} K_{0}-2 A \sqrt{I} /(1+\alpha \sqrt{I})+B I
$$

using the following values for the constants $\mathrm{p} K_{0}, A, \alpha$, and $B$ for sodium nitrate solutions: 4

$\begin{array}{rcccc}t^{\circ} \mathrm{C} & \mathrm{p} K_{0}{ }^{5} & A & \alpha & B \\ 15 & 4.7587 & 0.4974 & 0.1763 & 0.1557 \\ 20 & 4.7570 & 0.5017 & 0.1756 & 0.1495 \\ 25 & 4.7572 & 0.5062 & 0.1749 & 0.1442 \\ 35 & 4.7650 & 0.5163 & 0.1734 & 0.1373\end{array}$

These values were also used in the calculations relating to sodium nitrite solutions. 
Table 2. Potentiometric titration data for nitrous acid in aqueous sodium nitrate solutions at $15^{\circ}, 20^{\circ}, 25^{\circ}$, and $35^{\circ} \mathrm{C}$.

\begin{tabular}{|c|c|c|c|c|c|c|c|}
\hline \multirow{2}{*}{$\begin{array}{l}\text { Volume of } \\
\text { titrant } \\
\text { added, } \mathrm{ml}\end{array}$} & \multirow{2}{*}{$\frac{I \sim}{t,{ }^{\circ} \mathrm{C}}$} & \multirow[t]{2}{*}{0.09} & \multirow[t]{2}{*}{0.25} & \multirow[t]{2}{*}{0.50} & \multirow{2}{*}{$\frac{1.00}{\mathrm{pH}}$} & \multirow[t]{2}{*}{2.00} & \multirow[t]{2}{*}{4.00} \\
\hline & & & & & & & \\
\hline $\begin{array}{r}4.0 \\
\mathbf{4 . 5} \\
\mathbf{5 . 0} \\
\mathbf{5 . 5} \\
\mathbf{6 . 0} \\
\mathbf{6 . 5} \\
\mathbf{7 . 0} \\
\mathbf{7 . 5} \\
\mathbf{8 . 0} \\
\mathbf{8 . 5} \\
\mathbf{9 . 0} \\
\mathbf{9 . 5} \\
\mathbf{1 0 . 0}\end{array}$ & $\begin{array}{l}15 \\
15 \\
15 \\
15 \\
15 \\
15 \\
15 \\
15 \\
15 \\
15 \\
15 \\
15 \\
15\end{array}$ & $\begin{array}{l}4.059 \\
4.031 \\
4.001 \\
3.972 \\
3.953 \\
3.931 \\
3.912 \\
3.892 \\
3.876 \\
3.860 \\
3.845 \\
3.832 \\
3.818\end{array}$ & $\begin{array}{l}4.031 \\
\mathbf{3 . 9 9 7} \\
3.970 \\
3.946 \\
3.924 \\
3.903 \\
3.883 \\
3.866 \\
3.849 \\
3.832 \\
3.816 \\
3.804 \\
3.791\end{array}$ & $\begin{array}{l}4.015 \\
\mathbf{3 . 9 8 5} \\
\mathbf{3 . 9 5 5} \\
\mathbf{3 . 9 3 1} \\
\mathbf{3 . 9 0 9} \\
\mathbf{3 . 8 8 7} \\
\mathbf{3 . 8 7 0} \\
\mathbf{3 . 8 5 2} \\
\mathbf{3 . 8 3 3} \\
\mathbf{3 . 8 1 8} \\
\mathbf{3 . 8 0 3} \\
\mathbf{3 . 7 8 9} \\
\mathbf{3 . 7 7 5}\end{array}$ & $\begin{array}{l}4.014 \\
\mathbf{3 . 9 8 3} \\
\mathbf{3 . 9 5 5} \\
\mathbf{3 . 9 3 0} \\
\mathbf{3 . 9 0 6} \\
\mathbf{3 . 8 8 6} \\
\mathbf{3 . 8 6 8} \\
\mathbf{3 . 8 5 0} \\
\mathbf{3 . 8 3 4} \\
\mathbf{3 . 8 1 8} \\
\mathbf{3 . 8 0 4} \\
\mathbf{3 . 7 9 1} \\
\mathbf{3 . 7 7 8}\end{array}$ & $\begin{array}{l}4.066 \\
4.034 \\
4.010 \\
3.983 \\
\mathbf{3 . 9 6 1} \\
\mathbf{3 . 9 4 3} \\
\mathbf{3 . 9 2 4} \\
\mathbf{3 . 9 0 7} \\
\mathbf{3 . 8 9 1} \\
\mathbf{3 . 8 7 3} \\
\mathbf{3 . 8 5 9} \\
\mathbf{3 . 8 4 5} \\
\mathbf{3 . 8 3 2}\end{array}$ & $\begin{array}{l}4.274 \\
4.242 \\
4.212 \\
4.188 \\
4.165 \\
4.144 \\
4.127 \\
4.109 \\
4.094 \\
4.078 \\
4.062 \\
4.049 \\
4.036\end{array}$ \\
\hline $\begin{array}{r}4.0 \\
4.5 \\
\mathbf{5 . 0} \\
\mathbf{5 . 5} \\
\mathbf{6 . 0} \\
\mathbf{6 . 5} \\
\mathbf{7 . 0} \\
\mathbf{7 . 5} \\
\mathbf{8 . 0} \\
\mathbf{8 . 5} \\
\mathbf{9 . 0} \\
\mathbf{9 . 5} \\
\mathbf{1 0 . 0}\end{array}$ & $\begin{array}{l}20 \\
20 \\
20 \\
20 \\
20 \\
20 \\
20 \\
20 \\
20 \\
20 \\
20 \\
20 \\
20\end{array}$ & $\begin{array}{l}4.029 \\
4.003 \\
3.971 \\
3.946 \\
3.929 \\
3.909 \\
3.888 \\
3.871 \\
3.853 \\
3.836 \\
3.821 \\
3.806 \\
3.794\end{array}$ & $\begin{array}{l}4.008 \\
3.978 \\
3.951 \\
3.926 \\
3.904 \\
3.884 \\
3.865 \\
3.848 \\
3.831 \\
3.815 \\
3.801 \\
3.786 \\
3.772\end{array}$ & $\begin{array}{l}\mathbf{3 . 9 9 3} \\
\mathbf{3 . 9 6 7} \\
\mathbf{3 . 9 3 5} \\
\mathbf{3 . 9 1 0} \\
\mathbf{3 . 8 8 8} \\
\mathbf{3 . 8 6 6} \\
\mathbf{3 . 8 4 9} \\
\mathbf{3 . 8 3 2} \\
\mathbf{3 . 8 1 7} \\
\mathbf{3 . 8 0 0} \\
\mathbf{3 . 7 8 4} \\
\mathbf{3 . 7 7 0} \\
\mathbf{3 . 7 5 7}\end{array}$ & $\begin{array}{l}\mathbf{3 . 9 9 4} \\
\mathbf{3 . 9 6 3} \\
\mathbf{3 . 9 3 5} \\
\mathbf{3 . 9 1 2} \\
\mathbf{3 . 8 8 9} \\
\mathbf{3 . 8 6 8} \\
\mathbf{3 . 8 4 9} \\
\mathbf{3 . 8 3 3} \\
\mathbf{3 . 8 1 6} \\
\mathbf{3 . 8 0 2} \\
\mathbf{3 . 7 8 8} \\
\mathbf{3 . 7 7 5} \\
\mathbf{3 . 7 6 1}\end{array}$ & $\begin{array}{l}4.037 \\
4.009 \\
3.985 \\
3.961 \\
3.941 \\
3.920 \\
3.901 \\
3.885 \\
3.867 \\
3.851 \\
3.836 \\
3.822 \\
3.809\end{array}$ & $\begin{array}{l}4.236 \\
4.207 \\
4.179 \\
4.155 \\
4.133 \\
4.112 \\
4.095 \\
4.077 \\
4.061 \\
4.046 \\
4.035 \\
4.023 \\
4.009\end{array}$ \\
\hline $\begin{array}{r}4.0 \\
4.5 \\
5.0 \\
5.5 \\
6.0 \\
6.5 \\
7.0 \\
7.5 \\
8.0 \\
8.5 \\
9.0 \\
9.5 \\
10.0\end{array}$ & $\begin{array}{l}25 \\
25 \\
25 \\
25 \\
25 \\
25 \\
25 \\
25 \\
25 \\
25 \\
25 \\
25 \\
25\end{array}$ & $\begin{array}{l}4.020 \\
3.988 \\
3.963 \\
3.938 \\
3.918 \\
3.896 \\
3.877 \\
3.858 \\
3.841 \\
3.828 \\
3.814 \\
3.799 \\
3.786\end{array}$ & $\begin{array}{l}\mathbf{3 . 9 8 9} \\
\mathbf{3 . 9 5 7} \\
\mathbf{3 . 9 3 0} \\
\mathbf{3 . 9 0 5} \\
\mathbf{3 . 8 8 2} \\
\mathbf{3 . 8 6 1} \\
\mathbf{3 . 8 4 3} \\
\mathbf{3 . 8 2 5} \\
\mathbf{3 . 8 0 7} \\
\mathbf{3 . 7 9 3} \\
\mathbf{3 . 7 7 7} \\
\mathbf{3 . 7 6 4} \\
\mathbf{3 . 7 5 2}\end{array}$ & $\begin{array}{l}3.972 \\
3.941 \\
3.914 \\
3.886 \\
3.863 \\
3.842 \\
3.826 \\
3.810 \\
3.792 \\
3.777 \\
3.762 \\
3.752 \\
3.739\end{array}$ & $\begin{array}{l}\mathbf{3 . 9 7 1} \\
\mathbf{3 . 9 4 2} \\
\mathbf{3 . 9 1 4} \\
\mathbf{3 . 8 8 9} \\
\mathbf{3 . 8 6 7} \\
\mathbf{3 . 8 4 7} \\
\mathbf{3 . 8 2 8} \\
\mathbf{3 . 8 1 1} \\
\mathbf{3 . 7 9 4} \\
\mathbf{3 . 7 7 7} \\
\mathbf{3 . 7 6 4} \\
\mathbf{3 . 7 4 9} \\
\mathbf{3 . 7 3 6}\end{array}$ & $\begin{array}{l}4.019 \\
3.988 \\
3.963 \\
3.937 \\
\mathbf{3 . 9 1 8} \\
\mathbf{3 . 8 9 7} \\
\mathbf{3 . 8 8 0} \\
\mathbf{3 . 8 6 2} \\
\mathbf{3 . 8 4 5} \\
\mathbf{3 . 8 3 2} \\
\mathbf{3 . 8 1 8} \\
\mathbf{3 . 8 0 5} \\
\mathbf{3 . 7 9 2}\end{array}$ & $\begin{array}{l}4.203 \\
4.172 \\
4.145 \\
4.120 \\
4.098 \\
4.079 \\
4.062 \\
4.046 \\
4.029 \\
4.013 \\
3.998 \\
3.985 \\
3.973\end{array}$ \\
\hline $\begin{array}{r}4.0 \\
4.5 \\
5.0 \\
5.5 \\
6.0 \\
6.5 \\
7.0 \\
7.5 \\
8.0 \\
8.5 \\
9.0 \\
9.5 \\
10.0\end{array}$ & $\begin{array}{l}\mathbf{3 5} \\
\mathbf{3 5} \\
\mathbf{3 5} \\
\mathbf{3 5} \\
\mathbf{3 5} \\
\mathbf{3 5} \\
\mathbf{3 5} \\
\mathbf{3 5} \\
\mathbf{3 5} \\
\mathbf{3 5} \\
\mathbf{3 5} \\
\mathbf{3 5} \\
\mathbf{3 5}\end{array}$ & $\begin{array}{l}3.996 \\
3.965 \\
3.941 \\
3.918 \\
3.896 \\
3.875 \\
3.856 \\
3.838 \\
3.821 \\
3.806 \\
3.795 \\
3.781 \\
3.769\end{array}$ & $\begin{array}{l}\text { 3.962 } \\
\mathbf{3 . 9 3 7} \\
\mathbf{3 . 9 1 0} \\
\mathbf{3 . 8 8 6} \\
\mathbf{3 . 8 6 3} \\
\mathbf{3 . 8 4 1} \\
\mathbf{3 . 8 2 5} \\
\mathbf{3 . 8 0 9} \\
\mathbf{3 . 7 9 1} \\
\mathbf{3 . 7 7 5} \\
\mathbf{3 . 7 6 2} \\
\mathbf{3 . 7 5 0} \\
\mathbf{3 . 7 3 8}\end{array}$ & $\begin{array}{l}3.944 \\
3.914 \\
3.886 \\
3.865 \\
3.844 \\
3.822 \\
3.802 \\
3.786 \\
3.769 \\
3.755 \\
3.740 \\
3.727 \\
3.716\end{array}$ & $\begin{array}{l}\mathbf{3 . 9 3 6} \\
\mathbf{3 . 9 0 4} \\
\mathbf{3 . 8 7 7} \\
\mathbf{3 . 8 5 3} \\
\mathbf{3 . 8 3 0} \\
\mathbf{3 . 8 1 1} \\
\mathbf{3 . 7 9 1} \\
\mathbf{3 . 7 7 4} \\
\mathbf{3 . 7 5 8} \\
\mathbf{3 . 7 4 3} \\
\mathbf{3 . 7 3 0} \\
\mathbf{3 . 7 1 8} \\
\mathbf{3 . 7 0 5}\end{array}$ & $\begin{array}{l}\mathbf{3 . 9 7 8} \\
\mathbf{3 . 9 5 0} \\
\mathbf{3 . 9 2 4} \\
\mathbf{3 . 9 0 1} \\
\mathbf{3 . 8 7 9} \\
\mathbf{3 . 8 5 7} \\
\mathbf{3 . 8 4 0} \\
\mathbf{3 . 8 2 4} \\
\mathbf{3 . 8 0 7} \\
\mathbf{3 . 7 9 5} \\
\mathbf{3 . 7 8 0} \\
\mathbf{3 . 7 6 7} \\
\mathbf{3 . 7 5 4}\end{array}$ & $\begin{array}{l}4.153 \\
4.121 \\
4.099 \\
4.075 \\
4.052 \\
4.030 \\
4.012 \\
3.995 \\
3.980 \\
3.964 \\
3.952 \\
3.938 \\
3.926\end{array}$ \\
\hline
\end{tabular}


Table 3. Potentiometric titration data for nitrous acid in aqueous sodium nitrite solu. tions at $15^{\circ}, 20^{\circ}, 25^{\circ}$, and $35^{\circ} \mathrm{C}$.

\begin{tabular}{|c|c|c|c|c|c|c|}
\hline \multirow{2}{*}{$\begin{array}{c}\text { Volume of } \\
\text { titrant, } \\
\text { ml }\end{array}$} & \multirow{2}{*}{$\frac{I \sim}{t,{ }^{\circ} \mathrm{C}}$} & 0.09 & 0.25 & \multirow{2}{*}{$\frac{0.50}{\mathrm{pH}}$} & \multirow[t]{2}{*}{1.00} & \multirow[t]{2}{*}{2.00} \\
\hline & & & & & & \\
\hline 4.0 & 15 & 4.490 & 4.931 & 5.210 & 5.565 & 6.126 \\
\hline 4.5 & 15 & 4.457 & 4.871 & 5.155 & 5.501 & 6.029 \\
\hline 5.0 & 15 & 4.426 & 4.845 & 5.108 & 5.443 & 5.950 \\
\hline 5.5 & 15 & 4.397 & 4.812 & 5.073 & 5.394 & 5.884 \\
\hline 6.0 & 15 & 4.375 & 4.782 & 5.041 & 5.354 & 5.826 \\
\hline 6.5 & 15 & 4.353 & 4.754 & 5.005 & 5.318 & 5.772 \\
\hline 7.0 & 15 & 4.330 & 4.730 & 4.977 & 5.282 & 5.721 \\
\hline 7.5 & 15 & 4.308 & 4.706 & 4.950 & 5.248 & 5.677 \\
\hline 8.0 & 15 & 4.289 & 4.684 & 4.926 & 5.219 & 5.639 \\
\hline 8.5 & 15 & 4.275 & 4.661 & 4.900 & 5.194 & 5.606 \\
\hline 9.0 & 15 & 4.259 & 4.644 & 4.885 & 5.168 & 5.570 \\
\hline 9.5 & 15 & 4.243 & 4.631 & 4.865 & 5.144 & 5.542 \\
\hline 10.0 & 15 & 4.230 & 4.614 & 4.845 & 5.121 & 5.513 \\
\hline 4.0 & 20 & 4.468 & 4.889 & 5.182 & 5.529 & 6.083 \\
\hline 4.5 & 20 & 4.432 & 4.850 & 5.135 & 5.463 & 5.988 \\
\hline 5.0 & 20 & 4.399 & 4.818 & 5.085 & 5.412 & 5.908 \\
\hline 5.5 & 20 & 4.368 & 4.780 & 5.049 & 5.363 & 5.843 \\
\hline 6.0 & 20 & 4.348 & 4.746 & 5.017 & 5.322 & 5.785 \\
\hline 6.5 & 20 & 4.322 & 4.719 & 4.985 & 5.282 & 5.732 \\
\hline 7.0 & 20 & 4.301 & 4.694 & 4.954 & 5.249 & 5.686 \\
\hline 7.5 & 20 & 4.279 & 4.672 & 4.925 & 5.216 & 5.643 \\
\hline 8.0 & 20 & 4.262 & 4.651 & 4.905 & 5.187 & 5.604 \\
\hline 8.5 & 20 & 4.248 & 4.632 & 4.883 & 5.163 & 5.571 \\
\hline 9.0 & 20 & 4.233 & 4.613 & 4.860 & 5.138 & 5.536 \\
\hline 9.5 & 20 & 4.217 & 4.597 & 4.840 & 5.114 & 5.505 \\
\hline 10.0 & 20 & 4.203 & 4.582 & 4.821 & 5.092 & 5.479 \\
\hline 4.0 & 25 & 4.436 & 4.854 & 5.145 & 5.493 & 6.048 \\
\hline 4.5 & 25 & 4.404 & 4.818 & 5.096 & $\mathbf{5 . 4 3 0}$ & 5.952 \\
\hline 5.0 & 25 & 4.375 & 4.778 & 5.052 & $\mathbf{5 . 3 8 0}$ & 5.873 \\
\hline 5.5 & 25 & 4.344 & 4.747 & 5.012 & 5.331 & 5.810 \\
\hline 6.0 & 25 & 4.321 & 4.716 & 4.979 & 5.287 & 5.754 \\
\hline 6.5 & 25 & 4.299 & 4.688 & 4.949 & 5.250 & 5.703 \\
\hline 7.0 & 25 & 4.279 & 4.666 & 4.919 & 5.213 & 5.656 \\
\hline 7.5 & 25 & 4.261 & 4.643 & 4.892 & 5.183 & 5.614 \\
\hline 8.0 & 25 & 4.242 & 4.623 & 4.870 & 5.152 & 5.575 \\
\hline 8.5 & 25 & 4.225 & 4.604 & 4.847 & 5.128 & 5.544 \\
\hline 9.0 & 25 & 4.208 & 4.587 & 4.827 & 5.104 & 5.510 \\
\hline 9.5 & 25 & 4.192 & 4.568 & 4.807 & 5.080 & 5.482 \\
\hline 10.0 & 25 & 4.179 & 4.550 & 4.788 & 5.057 & 5.453 \\
\hline 4.0 & 35 & 4.406 & 4.815 & 5.093 & 5.442 & 5.967 \\
\hline 4.5 & 35 & $\mathbf{4 . 3 7 4}$ & 4.771 & 5.047 & 5.377 & 5.882 \\
\hline 5.0 & 35 & 4.345 & 4.743 & 5.004 & 5.324 & 5.806 \\
\hline 5.5 & 35 & 4.318 & 4.709 & 4.965 & 5.278 & 5.743 \\
\hline 6.0 & 35 & 4.294 & 4.678 & 4.933 & 5.236 & 5.689 \\
\hline 6.5 & 35 & 4.271 & 4.651 & 4.905 & 5.200 & 5.640 \\
\hline 7.0 & 35 & 4.250 & 4.625 & 4.874 & 5.167 & 5.595 \\
\hline 7.5 & 35 & 4.232 & 4.599 & 4.851 & 5.138 & 5.554 \\
\hline 8.0 & 35 & 4.215 & 4.582 & 4.828 & 5.112 & 5.517 \\
\hline 8.5 & 35 & 4.196 & 4.564 & 4.809 & 5.084 & 5.487 \\
\hline 9.0 & 35 & 4.185 & 4.546 & 4.786 & 5.061 & 5.456 \\
\hline 9.5 & 35 & 4.168 & 4.529 & 4.766 & 5.038 & 5.426 \\
\hline 10.0 & 35 & 4.153 & 4.511 & 4.750 & 5.017 & 5.404 \\
\hline
\end{tabular}


Table 4. Potentiometrically determined mean values of the protolysis constant of nitrous acid in aqueous sodium nitrate solutions at $15^{\circ}, 20^{\circ}, 25^{\circ}$, and $35^{\circ} \mathrm{C}$.

\begin{tabular}{lllll}
\hline$t^{\circ} \mathrm{C}$ & $I$ & $\sqrt{I}$ & $\mathrm{p} K$ (obs.) & pK(calc.) eqn. (5) \\
& & & & \\
15 & 0.0895 & 0.299 & 3.008 & 3.033 \\
15 & 0.250 & 0.500 & 3.000 & 2.977 \\
15 & 0.500 & 0.707 & 2.973 & 2.949 \\
15 & 1.000 & 1.000 & 2.938 & 2.940 \\
15 & 2.001 & 1.415 & 2.940 & 2.972 \\
15 & 4.003 & 2.001 & 3.095 & \\
& & & & \\
20 & 0.0895 & 0.299 & 2.964 & 2.987 \\
20 & 0.249 & 0.500 & 2.958 & 2.938 \\
20 & 0.500 & 0.707 & 2.937 & 2.915 \\
20 & 1.000 & 1.000 & 2.912 & 2.910 \\
20 & 2.000 & 1.414 & 2.909 & 2.943 \\
20 & 3.999 & 1.999 & 3.061 & 3.047 \\
& & & & \\
25 & 0.0894 & 0.299 & 2.938 & 2.953 \\
25 & 0.249 & 0.499 & 2.913 & 2.902 \\
25 & 0.499 & 0.706 & 2.894 & 2.876 \\
25 & 0.998 & 0.999 & 2.871 & 2.870 \\
25 & 1.997 & 1.413 & 2.879 & 2.902 \\
25 & 3.995 & 1.999 & 3.015 & 3.006 \\
35 & 0.0889 & 0.298 & 2.891 & 2.914 \\
35 & 0.248 & 0.498 & 2.875 & 2.854 \\
35 & 0.496 & 0.705 & 2.844 & 2.821 \\
35 & 0.993 & 0.997 & 2.799 & 2.808 \\
35 & 1.987 & 1.410 & 2.811 & 2.834 \\
35 & 3.975 & 1.994 & 2.947 & 2.937 \\
& & & &
\end{tabular}

The potentiometric data are given in Tables 2 and 3 and the values of $\mathrm{p} K$ of nitrous acid calculated from these are shown in Tables 4 and 5 . The values of $\mathrm{p} K$ are mean values computed from twenty-six experimental data.

As mentioned, the above values of the constants $\alpha$ and $B$ in eqn. (5) were used for acetic acid in aqueous sodium nitrate solutions. These values were also used for acetic acid in the calculation of the ionization constants of nitrous acid in sodium nitrite solutions (Series B). This was necessary because it is not possible to measure the $\mathrm{p} K$ values of acetic acid in sodium nitrite solutions. This may possibly have resulted in some inaccuracy in the $\mathrm{p} K$ values of nitrous acid in sodium nitrite solutions.

The values of the protolysis constant of nitrous acid can be represented by eqn. (5). The values of constant $A$ in eqn. (5) were the same, 0.5028 at $15^{\circ}$, 0.5070 at $20^{\circ}, 0.5115$ at $25^{\circ}$, and 0.5211 at $35^{\circ} \mathrm{C},{ }^{6}$ when calculating the values of the protolysis constant of nitrous acid in both series of solutions. The values of the constants $\mathrm{p} K_{0}, \alpha$, and $B$ in this equation calculated by applying the method of least squares to the values of $\mathrm{p} K$ and ionic strength in Tables 4 and 5 are given in Table 6 . The values determined earlier ${ }^{2-3}$ for nitrous acid in sodium perchlorate solutions are also given for comparison.

Acta Chem. Scand. 22 (1968) No. 6 
Table 5. Potentiometrically determined mean values of the protolysis constant of nitrous acid in aqueous sodium nitrite solutions at $15^{\circ}, 20^{\circ}, 25^{\circ}$, and $35^{\circ} \mathrm{C}$.

\begin{tabular}{lllll}
\hline$t^{\circ} \mathrm{C}$ & $I$ & $\sqrt{I}$ & $\mathrm{p} K$ (obs.) & $\mathrm{p} K$ (calc.) eqn. (5) \\
\hline 15 & 0.0868 & 0.295 & 3.045 & \\
15 & 0.237 & 0.486 & 3.045 & 3.056 \\
15 & 0.471 & 0.686 & 3.036 & 3.027 \\
15 & 0.939 & 0.969 & 3.079 & 3.093 \\
15 & 1.874 & 1.369 & 3.261 & 3.256 \\
20 & & & & \\
20 & 0.0868 & 0.295 & 3.001 & 3.010 \\
20 & 0.236 & 0.486 & 3.002 & 2.990 \\
20 & 0.470 & 0.686 & 3.012 & 3.002 \\
20 & 0.938 & 0.968 & 3.044 & 3.062 \\
& 1.873 & 1.368 & 3.221 & 3.215 \\
25 & & & & \\
25 & 0.0867 & 0.294 & 2.962 & 2.970 \\
25 & 0.236 & 0.486 & 2.960 & 2.947 \\
25 & 0.470 & 0.685 & 2.967 & 2.959 \\
25 & 0.937 & 0.968 & 3.006 & 3.023 \\
35 & 1.870 & 1.368 & 3.192 & 3.187 \\
35 & & & & \\
35 & 0.0862 & 0.293 & 2.911 & 2.917 \\
35 & 0.235 & 0.485 & 2.902 & 2.893 \\
35 & 0.467 & 0.684 & 2.909 & 2.904 \\
& 1.861 & 0.965 & 2.952 & 2.964 \\
& & 1.364 & 3.125 & 3.121
\end{tabular}

Our earlier studies ${ }^{3}$ and the present investigation show that it is possible to calculate $\mathrm{p} K_{0}$ values in a narrow temperature range by extrapolating $\mathrm{p} K$ values measured at a low ionic strength (0.25 in this case) to zero ionic strength by using in eqn. (5) values of the constants $\alpha$ and $B$ determined at one point in the temperature range. This is seen from the values for sodium perchlorate solutions in Table 6 . The $\mathrm{p} K_{0}$ values in the different salt solutions are equal within the limits of experimental error.

Table 6. Values of the constants of eqn. (5) for nitrous acid calculated by the method of least squares on the basis of the data in Tables 4 and 5 . Corresponding data determined previously ${ }^{2-3}$ for nitrous acid in sodium perchlorate solution are also included.

\begin{tabular}{|c|c|c|c|c|c|c|c|c|c|c|}
\hline \multirow[b]{2}{*}{$t^{\circ} \mathrm{C}$} & \multicolumn{3}{|c|}{$\mathrm{NaNO}_{3}$ solutions } & \multicolumn{3}{|c|}{$\mathrm{NaNO}_{3}$ solutions } & \multicolumn{3}{|c|}{$\mathrm{NaClO}_{4}$ solutions } & \multirow{2}{*}{$\begin{array}{c}\text { Mean } \\
\mathbf{p} K_{0}\end{array}$} \\
\hline & $\mathrm{p} K_{0}$ & $\alpha$ & $B$ & $\mathrm{p} K_{0}$ & $\alpha$ & $B$ & $\mathrm{p} K_{0}$ & $\alpha$ & $B$ & \\
\hline 15 & 3.220 & 1.852 & 0.0722 & 3.222 & 2.033 & 0.212 & 3.230 & - & - & 3.224 \\
\hline 20 & 3.166 & 2.152 & 0.0660 & 3.162 & 2.604 & 0.191 & 3.203 & - & - & 3.177 \\
\hline 25 & 3.136 & 2.074 & 0.0669 & 3.130 & 2.362 & 0.207 & 3.148 & 1.622 & 0.261 & 3.138 \\
\hline 35 & 3.110 & 1.789 & 0.0708 & 3.078 & 2.422 & 0.200 & 3.113 & - & - & 3.100 \\
\hline
\end{tabular}




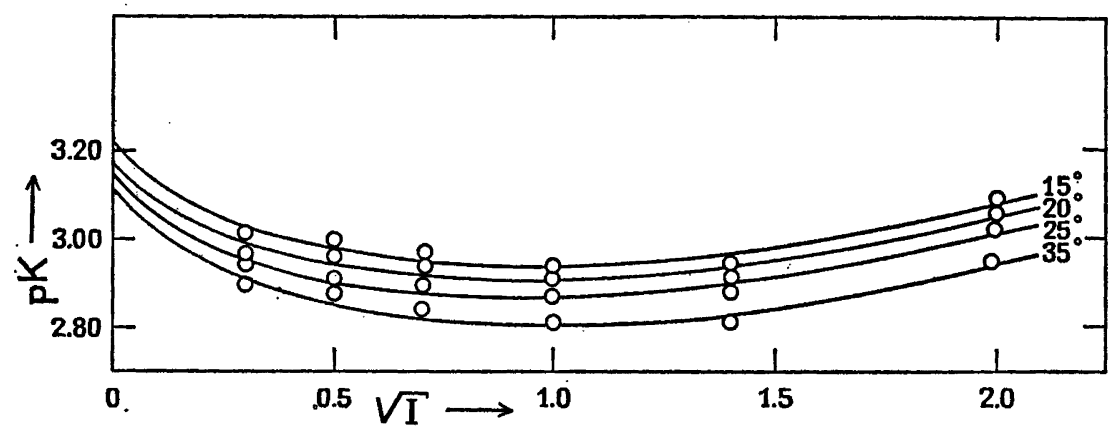

Fig. 1. The values of $\mathrm{p} K$ of nitrous acid in aqueous sodium nitrate solutions as a function of the square root of the ionic strength at $15^{\circ}, 20^{\circ}, 25^{\circ}$, and $35^{\circ} \mathrm{C}$.

In this connection it may be pointed out that the change in the $\mathrm{p} K$ value of acetic acid at ionic strength 0.25 is only $0.7 \%$ from $15^{\circ}$ to $35^{\circ} \mathrm{C}$. (At ionic strength 2.00 the change is about $13 \%$ in the same temperature range).

Attempts were also made to determine $\mathrm{p} K$ values at an ionic strength of 0.04 , but the values of $\mathrm{p} K$ were too low because of diffusion potentials in the systems and are not presented.

The effects of sodium nitrate and sodium nitrite on the protolysis constant of nitrous acid at different temperatures are seen in Figs. 1 and 2.

The dependence of the $\mathrm{p} K$ value of nitrous acid on salt concentration in sodium perchlorate, ${ }^{2}$ sodium nitrate, and sodium nitrite solutions at $25^{\circ} \mathrm{C}$ is shown in Fig. 3. From the figure it is apparent that the effects of sodium perchlorate and sodium nitrite are nearly equal, but the effect of sodium nitrate is much smaller. The former fact is an advantage when the formation of metal nitrite complexes in solutions containing both sodium perchlorate and sodium nitrite are studied.

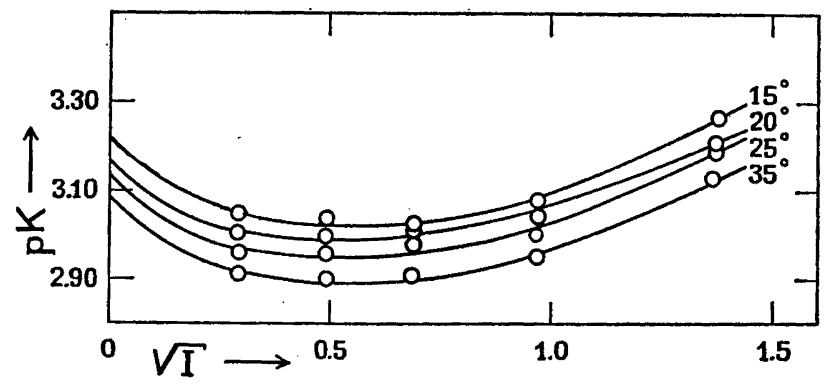

Fig. 2. The values of $\mathrm{p} K$ of nitrous acid in aqueous sodium nitrite solutions as a function of the square root of the ionic strength at $15^{\circ}, 20^{\circ}, 25^{\circ}$, and $35^{\circ} \mathrm{C}$. 


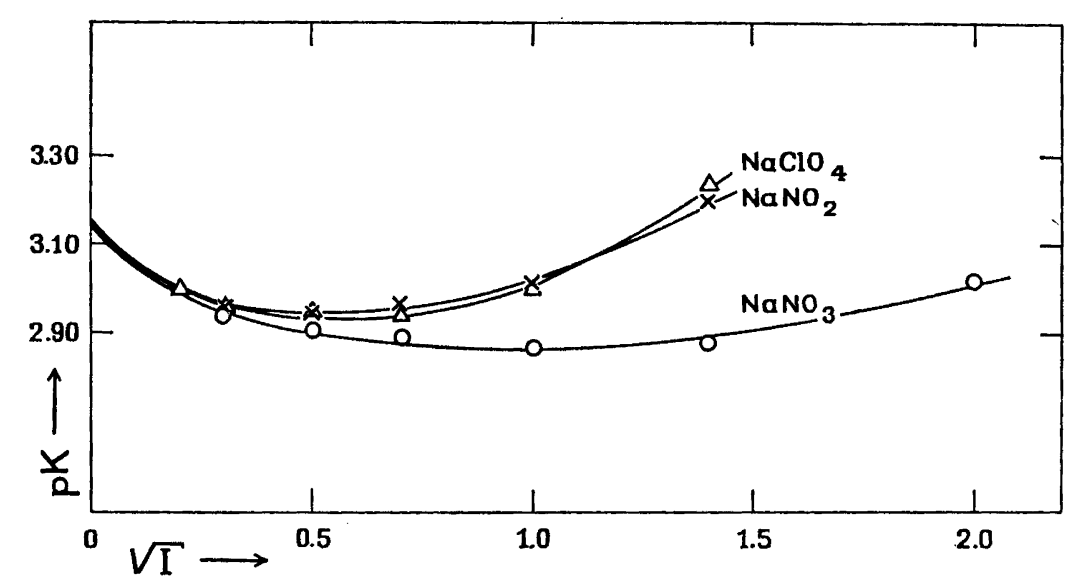

Fig. 3. The values of $\mathrm{p} K$ of nitrous acid as functions of the square root of the ionic strength in aqueous sodium perchlorate, nitrate and nitrite solutions at $25^{\circ} \mathrm{C}$.

B. The thermodynamics of the protolysis

The mean values of the thermodynamic protolysis constants $p K_{0}$ of nitrous acid in Table 6 were assumed to vary with temperature as shown by the equation ${ }^{7}$

$$
\log K_{0}=-(a / T)-c T+b
$$

The values of the constants $a, b$, and $c$ of eqn. (6) were calculated by fitting this equation to the mean values of $\mathrm{p} K_{0}$ by the method of least squares. The values were found to be

$$
\begin{array}{rcc}
a \times 10^{-3} & b & c \times 10^{3} \\
5.8554 & 34.558 & 60.571
\end{array}
$$

By differential calculus it follows from eqn. $(6)^{3}$ that

and

$$
\log K_{0, \max }=b-2(a c)^{0.5}
$$

$$
T_{\max }=(a / c)^{0.5}
$$

The values for nitrous acid are

$$
T_{\max }=311^{\circ} \mathrm{K} \text { and } \log K_{0, \max }=-3.11 \text {. }
$$

The changes in the standard free energies, enthalpies, entropies and heat capacities of the protolytic reaction of nitrous acid were calculated from the equations:

$$
\begin{aligned}
\Delta G^{\circ} & =2.303 R\left(a-b T+c T^{2}\right) \\
\Delta H^{\circ} & =2.303 R\left(a-c T^{2}\right)
\end{aligned}
$$


Table 7. Thermodynamic quantities for the protolysis of nitrous acid in water.

\begin{tabular}{|c|c|c|c|c|c|c|c|c|}
\hline$t,{ }^{\circ} \mathrm{C}$ & $\begin{array}{l}\text { Mean p } K_{0} \\
\text { (Eqn. (5)) }\end{array}$ & $\begin{array}{c}\mathrm{p} K_{0} \\
\text { (Eqn. }(6))\end{array}$ & $\begin{array}{c}\Delta G^{\circ} \\
\text { (kcal) }\end{array}$ & $\begin{array}{c}\Delta H^{\circ} \\
(\text { kcal) }\end{array}$ & $\begin{array}{l}\Delta S^{\circ} \\
\text { (e.u.) }\end{array}$ & $\begin{array}{l}\Delta C \mathrm{p}^{\circ} \\
\text { (cal) }\end{array}$ & $-T \Delta S^{\circ}$ & 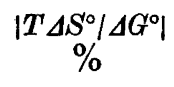 \\
\hline $\begin{array}{l}15 \\
20 \\
25 \\
35\end{array}$ & $\begin{array}{l}3.224 \\
3.177 \\
3.138 \\
3.100\end{array}$ & $\begin{array}{l}3.216 \\
3.173 \\
3.141 \\
3.109\end{array}$ & $\begin{array}{l}4.24 \\
4.26 \\
4.29 \\
4.38\end{array}$ & $\begin{array}{l}3.8 \\
3.0 \\
2.2 \\
0.47\end{array}$ & $\begin{array}{r}-1.6 \\
-4.4 \\
-7.1 \\
-12.7\end{array}$ & $\begin{array}{l}-160 \\
-163 \\
-165 \\
-171\end{array}$ & $\begin{array}{l}0.46 \\
1.28 \\
2.13 \\
3.91\end{array}$ & $\begin{array}{l}11 \\
30 \\
50 \\
89\end{array}$ \\
\hline \multicolumn{8}{|c|}{$\Delta S^{\circ}=2.303 R(b-2 c T)$} & $\begin{array}{l}(11) \\
(12)\end{array}$ \\
\hline
\end{tabular}

where $T=273.16+t^{\circ} \mathrm{C}$ and $R=1.9873 \mathrm{cal}^{\mathrm{c}} \mathrm{degree}-1 \mathrm{~mole}^{-1}$. The values of the thermodynamic quantities for the protolysis of nitrous acid in water are shown in Table 7. These values are of the same magnitude as obtained earlier for the protolysis of nitrous acid in aqueous sodium perchlorate solutions ${ }^{3}$ and do not alter the earlier conclusions about the thermodynamics of protolysis of nitrous acid.

Acknowledgements. This work was supported by a grant from the State Commission for Natural Sciences, which aid is gratefully acknowledged. One of us (J.T.) is also grateful to the Emil Aaltonen Foundation for a grant.

\section{REFERENCES}

1. Lumme, P., Lahermo, P. and Tummavuori, J. Tidssk. Kjemi, Bergvesen, Met. (1965) Nos. 8-9.

2. Lumme, P. and Tummavuori, J. Acta Chem. Scand. 19 (1965) 617.

3. Lumme, P., Lahermo, P. and Tummavuori, J. Acta Chem. Scand. 19 (1965) 2175.

4. Ellilä, A. Ann. Acad. Sci. Fennicae Ser. A II 51 (1952).

5. Harned, H. S. and Ehlers, R. W. J. Am. Chem. Soc. 54 (1932) 1350.

6. Bates, R. G. Determination of $p H$, New York 1964, p. 403.

7. Harned, H. S. and Robinson, R. A. Trans. Faraday Soc. 36 (1940) 973.

Received February 2, 1968. 